\title{
CHAPTER 3 \\ DEVELOPMENT OF THE FIRM THEORY BY NEW \\ INSTITUTIONAL ECONOMICS: METHODOLOGY, CONCEPTS, AND MODELS
}

\section{Horniak O. V.}

\section{INTRODUCTION}

The modern development stage of economic theory is characterized by cardinal shifts in the methodology, conceptual approaches to solving urgent scientific and practical problems. Despite the fact that already in the 60 s and 70s of the XX century, neoclassical theory and neoclassical synthesis as a mainstream of economic science were criticized, above all, due to disconnect from the practice of management, its tools, methodological principles continue to be used in the study of modern economic processes. At the same time, one should pay attention to the fact that the theory of the firm as a component of the general economic theory to some extent differs in that the theoretical abstract structures are gradually replaced there by modern models, reflecting some progress in the study of real firms and the retreat from the interpretation of a firm as a "black box", as a model that "is not intended to explain and anticipate the behaviour of specific firms; on the contrary, it should explain and anticipate changes in prices ... arising as a result of certain changes in conditions (wage rates, interest rates, import duties, taxes, technologies, etc.)"

New approaches and concepts such as the new institutional economic theory, evolutionary theory of economic change are different in that here the firm is the main object of research. This is associated with a change in the role and importance of firms in the real economy with changes that take place in the very firm. The theoretical substantiation of the shifts in the modern economy, in the functioning of firms, requires appropriate methodological tools, new conceptual approaches, and modern models that would reflect the peculiarities of

\footnotetext{
${ }^{1}$ Machlup, F. (1999). Teorii firmy: marzhinalistskiye, bikhevioristkiye i upravlencheskiye [Theories of the firm: marginalist, behavioral and managerial]. Milestones of economic thought. St. Petersburg: School of Economics. (in Russian)
} 
the development of the main organizational and economic unit of the economic process.

\subsection{Methodological principles of analysis of modern firms}

The formation of the modern theory of the firm provides an opportunity, firstly, to deeply explore the national economy, its development prospects, trends, and competitive advantages, as it is known that the latter are developed and supported by firms representing the national economy in world markets. Secondly, firms are a complex entity where the economic and social interests, problems and goals of society, the realization and achievement of which they provide, are intertwined. Therefore, the study of a firm in the conceptual context is important both for the development of economic science and for the effective functioning of firms of the real economy, for the development of economic, social relations and socio-economic system.

At one time, K. Polanyi described the role of firms in economic processes: "Undoubtedly, labour, land, and money markets are essential to a market economy. But no society could stand the effects of such a system of crude fictions even for the shortest stretch of time unless its human and natural substance, as well as its business organization, was protected against the ravages of this satanic mill.",2

Research of the modern firm was most fully conducted by representatives of the new institutional economic theory, including A. Alchian, M. Aoki, O. E. Williamson, S. J. Winter, H. Demsetz, P. Joskow, T. Eggertsson, R. Coase, C. Menard, D. Morris, P. Milgrom, D. North, R. Nelson, J. Tirole, E. Furubotn, O. Hart, G. Hodgson, D. Hay. In their works, the methodological principles of the analysis of a modern firm are revealed, concepts and models are developed. However, modern firms, constantly developing, require further research on their essence, forms, the interaction between them and the state, market mechanisms, other organizational formations that form the modern economic space. In this paper, the main purpose is the critical reevaluation of existing approaches and the development of some areas for the development of a modern firm that take into account the changes occurring at the micro level, in the context of methodology, theory, and development models' formation.

\footnotetext{
${ }^{2}$ Polanyi, K. (1993). Samoreguliruyushchiysya rynok i fiktivnyye tovary: trud, zemlya i dengi [Selfregulating market and fictitious goods: labor, land and money]. Thesis. T. 1. Vyp. 2, s. 15. (in Russian)
} 
The formation of new methodological approaches in the firm's research is explained by the fact, as T. Eggertsson writes, that neoclassical theory left out of the attention such research areas as alternative social rules (property rights) and types of economic activity that significantly affect the behaviour of economic agents, the allocation of resources and equilibrium; various forms of economic organizations; economic logic, and changes in fundamental social and political rules governing production and exchange ${ }^{3}$. It should be noted that within the framework of the neoclassical theory, attempts were made to introduce these problems into the analysis, but the new theories were not developed since the methodological approaches did not change and the main theoretical postulates remained: rational choice and equilibrium state.

In economic theory, since the 70s of the XX century following the work by I. Lakatos ${ }^{4}$, the idea is affirmed that studies within one or another theory consist of a solid core and a protection belt. The solid core is unchanged, and the protective belt changes under the influence of various modifications. If the core changes, this means the rejection of the old theory and the transition to a new one, the formation of a new paradigm based on new methodological approaches and principles. The neoclassical theory is based on such postulates as rational choice, equilibrium, and persistent advantages that form its solid core. The protection belt of the neoclassical theory consists of the following elements, which were defined in due time by C. Knudsen ${ }^{5}$ : the exact definition of the restrictions that the economic agent must take into account; a clear definition of the type of information available to the agents. If we consider the neoinstitutional economic theory from the viewpoint of such methodological approaches, then we can somewhat agree with T. Eggertsson ${ }^{6}$ that all its directions, beginning with the theory of transaction costs, the theory of property rights and ending with a new economic history, a new comparative theory of economic systems, can be interpreted as modification of the protection belt of the neoclassical

\footnotetext{
${ }^{3}$ Eggertsson, T. (2001). Ekonomicheskoye povedeniye i instituty [Economic behavior and institutions]. Moscow: Business. (in Russian)

${ }^{4}$ Lakatos, Imre (1970). Falsification and the Methodology of Scientific Research Programs, Cambridge: Cambridge University Press.

5 Knudsen, Christian (1986). Normal Science as a Process of Creative Destruction: From a Microeconomic to a Neoinstitutional Research Program. Paper presented at the International Symposium on Property Rights Organizational Forms and Economic Behavior. (P. 10). Lund: The Swedish Collegium for Advanced Study in the Social Sciences.

${ }^{6}$ Eggertsson, T. (2001). Ekonomicheskoye povedeniye i instituty [Economic behavior and institutions]. Moscow: Business. (in Russian)
} 
economic theory by including it in transaction and information costs and restrictions on property rights.

Another direction of research in line with the new institutional theory refuses the model of rational choice, that is, it begins to change the core of the neoclassical theory, initiating a new paradigm. The new institutional economic theory is at an early development stage. It is characterized by the formality of categorical framework, some refusal from mathematical models but, along with that, extensive empirical studies are carried out. Economists working within the framework of neoinstitutional economic theory and the new institutional economic theory develop common approaches (modelling of constraints, the existence of transaction costs, the study of qualitative characteristics of goods and services, their impact on the economic performance of firms), indicating the convergence of these two directions.

The transition to new methodological principles is carried out gradually; therefore, a rational choice of individual agents, which maximize the target function under certain constraints, still plays the main role in neoinstitutional economic theory. At the same time, research concentrates around the definition of the target function in the presence of alternative opportunities. Under such conditions, the maximization of profits by firms, which made sense in perfect competition, complete information, and definite property rights, is inferior to a satisfactory result, which was substantiated by $\mathrm{H}$. Simon in the theory of behaviour? ${ }^{7}$. He believed that the rationality of people is limited and it forces them to be satisfied with the result, adequate to their wishes. In the course of achieving such a result, the behaviour of a rational individual means that not only objective but also subjective factors of this activity are taken into account.

Such an interpretation of the model of rational behaviour means the change of the solid core of the neoclassical theory and the formation of new methodological approaches to the analysis of activities of individuals and firms. According to T. Eggertsson, “...the task of the institutional economy is to rise above methodological criticism and develop an effective program of scientific research".

\footnotetext{
${ }^{7}$ Simon, G. A. (1999). Teoriya prinyatiya resheniy $\mathrm{v}$ ekonomicheskoy teorii i nauke o povedenii [Decision making theory in economics and behavior science]. Milestones of economic thought (T. 2. The theory of the company). St. Petersburg: School of Economics. (in Russian)

${ }^{8}$ Eggertsson, T. (2001). Ekonomicheskoye povedeniye i instituty [Economic behavior and institutions]. Moscow: Business. (in Russian)
} 
The new institutional economic theory has restored interest in the institutions and, hence, in the fundamental issues regarding the nature of the firm ${ }^{9}$. It is possible to reveal the nature of the firm as an institution based on its delineation with other institutions, first of all, the market. This approach allows dividing all institutions into the market and nonmarket and determining their interaction in the process of economic activity. The most typical non-market institution is a firm characterized by a hierarchy, authoritarian relations, which radically distinguishes it from the market with its freedom and formal equality. The common feature of these two institutions is the division of labour; nevertheless, the specific differences are much more significant.

In economic theory, there is also another point of view, which denies the fundamental difference between the market and the firm. It is presented in the article by A. Alchian and H. Demsetz, where they substantiate the idea that there are no significant differences between the firm and the market. Market exchange and employment contract in the firm do not differ from each other. As a result, the existence of the firm's hierarchical relations, the power relations between the employee and the employer, which, according to A. Alchian and H. Demsetz, are symmetrical, an agreement to exchange service for service, is denied. An employee dismisses an employer when he chooses to resign from the firm, in the same way as the employer dismisses the employee. But they also see one important difference between these institutions, which is associated with the fact that production is collective and it is necessary to measure the contribution and remuneration of each employee. In order to avoid the workers' shirking from work, control over their actions is required by the employer, who receives income from the establishment of labour prices and other factors of production, as well as the control over their effective use. At the same time, they believe that the employment contract should be constantly reviewed, but under such circumstances, it will be virtually impossible to organize production.

Therefore, most economists working in this direction, believe that, firstly, the firm and the market are two different types of institutions, and secondly, the firm concludes incomplete contracts and, therefore, during the period of their actions, the employer receives certain powers

\footnotetext{
9 Hojon, J. (2003). Ekonomicheskaya teoriya i instituty: Manifest sovremennoy institutsionalnoy ekonomicheskoy teorii [Economic Theory and Institutions: The Manifesto of Modern Institutional Economic Theory]. Moscow: Business. (in Russian)
} 
that provide control over the efficient use of resources in the production process.

The conceptual difference between the firm and the market, based on the methodology of neoinstitutional economic theory, was first substantiated by R. Coase, emphasizing that the main characteristic of the firm is the displacement of the mechanism and the allocation of resources not through prices but regularly ${ }^{10}$, at the same time, the market is based on the system of prices and their dynamics and coordinated by exchange transactions. In the firm, processes are coordinated by the entrepreneur. Firms exist because they make it possible to reduce the cost of using the price mechanism. O. E. Williamson, developing the approaches of R. Coase, confirms that the main goal and the result of the functioning of institutions of the firm type is the minimization of transaction costs ${ }^{11}$ but herewith their definition as a category is not provided. This leads to the fact that they are often reduced to direct expenses, that is, to a part of the firm's expenses. But for such an interpretation, it is difficult to imagine them as one of the important foundations of neoinstitutional economic theory. At the same time, there are works in which more in-depth studies of the essence of the category of transaction costs have been carried out, as discussed in the second part of this research paper.

An important element of the firm's research methodology in the context of neoinstitutionalism is uncertainty since it is inherent both in theoretical constructions and in real economic processes. According to G. Hodgson, "....in a world of uncertainty, where the probabilistic calculus is ruled out, rules, norms and institutions play a functional role in providing a basis for decision-making, expectation and belief." 12 Uncertainty creates the need for rules, norms, social routines, and habits that enable economic agents to make decisions. All these tools combine subjective and objective aspects. Understanding this is important for developing the theory of the firm.

Under market conditions, price mechanisms and norms that are recognized as economic agents are created. They are the result of the action of objective laws and regularities. The firm does not have such

\footnotetext{
10 Coase, R. (2001). Priroda firmy [The nature of the firm]. The nature of the company. Ed. O. Williamson and S. J. Winter Moscow: Business. (in Russian)

11 Williamson, O. E. (2001). Ekonomichni instytutsiyi kapitalizmu. Firma, marketynh, ukladannya kontraktiv [Economic institutions of capitalism. Firm, marketing, contracting]. Kyiv: ArtEk. (in Ukrainian)

${ }^{12}$ Hojon, J. (2003). Ekonomicheskaya teoriya i instituty: Manifest sovremennoy institutsionalnoy ekonomicheskoy teorii [Economic Theory and Institutions: The Manifesto of Modern Institutional Economic Theory]. Moscow: Business. (in Russian)
} 
mechanisms since the exchange as such is not inherent to it. Therefore, the effectiveness of rational calculations of costs and benefits in the firm decreases and even reduces to zero because it becomes impossible over the lack of objective information on prices and costs.

The institutional solution to the problem of uncertainty, as emphasized by G. Hodgson, is fundamentally different within the firm compared with the market. The market, creating rules and regulations, gives them legal force through the interaction of relatively independent agents that have no long-term commitments with each other. The firm as a social institution forms other rules and regulations on an ongoing basis. The rules and regulations of the market relate to price parameters while the rules and regulations of the firm cannot form them ${ }^{13}$. But the paradox is that the uncertainty in the firm requires a rational calculation of costs and profits, which is more important for the firm than for the market. Therefore, the nature and causes of the firm's appearance are disclosed not in the minimization of transaction costs but in the formation of an institutional structure that can replace to some extent the measurement of costs existing in the market. Such institutional structure creates peculiar additional mechanisms based on trust, habits, traditions that may have a cognitive character, be subconscious and quite unique for each individual firm. It is about a fact that the firm's function is to produce and reproduce the rules, habits, routines that provide the appropriate level of its effective operation over a long period of time and constitute an alternative to a rational calculation of costs and profits generated by the market.

The firm forms and maintains habits and traditions because they embody skills and information accumulated throughout its existence. They cannot always be calculated, and their institutionalization takes place within the organizational structure, which makes them permanently stable and protected from the unfettered market forces. R. Nelson and S. Winter, following T. Veblen, substantiated that the firm has the ability to maintain and reproduce a large number of habits and routines that are similar to genes $^{14}$. The firm, accumulating skills, knowledge, and technologies that form its production potential, is a rather stable institute

\footnotetext{
13 Hojon, J. (2003). Ekonomicheskaya teoriya i instituty: Manifest sovremennoy institutsionalnoy ekonomicheskoy teorii [Economic Theory and Institutions: The Manifesto of Modern Institutional Economic Theory]. Moscow: Business. (in Russian)

14 Nelson, R. R., \& Winter S. J. (2000). Evolyutsionnaya teoriya ekonomicheskikh izmeneniy [The evolutionary theory of economic change]. Moscow: ZAO Finstatinform. (in Russian)
} 
and successfully operates in conditions of uncertainty, both external and internal. It overcomes external uncertainty by means of internal unity and organic interconnection of all its components, and internal one - by means of changes, evolution, modernization of its structure.

\subsection{Concepts and models of modern firms}

Within the framework of the new institutional economic theory, several directions of research of the firm have been formed. One of the first such concepts developed by R. Coase is the theory of transaction costs. It clearly delineates the firm and market and explores the causes and nature of the firm. The theory of R. Coase is based on the following principles: resource constraints and choice; limited rationality of the behaviour of economic agents and opportunism; market transactions on a paid basis and the choice between them and the firm. The reason for the occurrence of transaction costs is market transactions on a paid basis, and the reason for the occurrence of the firm is the difference between the size of market transaction costs and related costs of the firm. R. Coase also determines limits of a firm by the level of internal transaction costs, which at a certain stage of the firm's development become higher compared to the market, and the entrepreneur begins to conclude a part of the internal contracts in the market. This allows reducing total transaction costs and optimizing firm size. Herewith, R. Coase defines transaction costs as "the cost of using the price mechanism". ${ }^{15}$

The theory of transaction costs was further developed in the work of O. E. Williamson, who interpreted transaction costs as "the economic counterpart of friction in physics". ${ }^{16}$ Economists interpret the essence of transaction costs differently. Since their occurrence is associated with the need for information search, as T. Eggertsson writes, "transaction costs reflect the scarcity of information,"17 they are interpreted as an element of information costs. In the conditions of complete and reliable information, transaction costs are zero.

If in the theory of transaction costs they are considered as an element of information costs, then in public choice theory they are

15 Coase, R. (2001). Priroda firmy [The nature of the firm]. The nature of the company. Ed. O. Williamson and S. J. Winter Moscow: Business. (in Russian)

${ }^{16}$ Williamson, O. E. (2001). Ekonomichni instytutsiyi kapitalizmu. Firma, marketynh, ukladannya kontraktiv [Economic institutions of capitalism. Firm, marketing, contracting]. Kyiv: ArtEk. (in Ukrainian)

${ }^{17}$ Eggertsson, T. (2001). Ekonomicheskoye povedeniye i instituty [Economic behavior and institutions]. Moscow: Business. (in Russian) 
associated with the agreements on the use of public goods. In the opinion of researchers, they arise in the process of reimbursement of public goods and their transfer by the parties to the agreement on each other. Contract theory interprets transaction costs as the cost of harmonizing different regulations governing different spheres of life. Asymmetry of information generated by the coexistence of different systems of information and access to it facilitates the use of certain norms for own benefit ${ }^{18}$. G. Hodgson studies transaction costs in the context of the comparative effectiveness of the firm and believes that the explanation of the reasons for its occurrence, its essence only in terms of transaction costs is insufficient. He pays special attention to the fact that "the existence of the firm is partly explained by its ability to protect and maintain routines [due to which skills are transferred and production is supported] within its institutional structure."19 This is confirmed by the fact that, according to G. Hodgson, firms conclude non-market agreements with other firms and organizations on a longterm basis, which forms additional security features against the unfettered market forces. In the process of cooperation of activities, mutual trust between firms is formed on the basis of such agreements, which contributes to reducing the costs of mutual control and monitoring of contract execution. Although relations between firms can be unequal in this case, the benefits of such interconnections neutralize such inequality to a certain extent.

Trust support within the firm is also an important condition for ensuring its sustainability and efficiency. The trust of workers, managers, and owners is very important since, as R. Nelson emphasizes, "only a small fraction of what people actually do at work are subject to detailed control". ${ }^{20}$ In relation to this, trust and cooperation become functional for the firm and where they become an element of corporate culture, productivity can grow. Support for trust is an important prerequisite for

\footnotetext{
${ }^{18}$ Eggertsson, T. (2001). Ekonomicheskoye povedeniye i instituty [Economic behavior and institutions]. Moscow: Business. (in Russian); Arkhiiereev, S.I. (2005). Transaktsionnyye izderzhki institutsionalizatsii fondovogo rynka [Transaction costs institutionalization of the stock market]. Kharkiv. (in Russian); Gornyak, O. V. (2004). Firma v ekonomichniy teoriyi ta praktytsi hospodaryuvannya [Firm in Economic Theory and Practice of Management]. Odessa: Astroprint. (in Ukrainian)

19 Hojon, J. (2003). Ekonomicheskaya teoriya i instituty: Manifest sovremennoy institutsionalnoy ekonomicheskoy teorii [Economic Theory and Institutions: The Manifesto of Modern Institutional Economic Theory]. Moscow: Business. (in Russian)

${ }^{20}$ Nelson, R. R. (1981) Research of productivity Growth and Productivity Differences: Dead Ends and New Departures. Journal of Economic Literature, 29, 1029-64.
} 
its effectiveness, which is also confirmed by empirical studies ${ }^{21}$. Under such conditions, the level of opportunism in the firm significantly decreases. It is kept within certain limits, which also has a positive effect on the results of work. Therefore, it can be concluded that the firm exists and develops because it is able to form a consistent type of behaviour of its employees, which differs from the antagonistic behaviour of market participants. This indicates the influence of the institutional environment on the formation of economic behaviour. The institutional environment of the market forms a competitive, antagonistic type of behaviour, and the institutional environment of the firm forms a type of behaviour based on trust, cooperation, and the decline of opportunism. Therefore, the key to ensuring the effectiveness of the firm is not only the resources, prices, costs but also the level of trust and cooperation of employees.

The first approach to a modern firm corresponds not only to the institutional tradition but also to objective processes that occur in real production and real firms. The networking of the modern economy raises the problem of trust as one of the priorities at the level of inter-firm, inter-organizational networks. Individualization of modern production requires taking into account individual consumer needs, building trust between the producer and the consumer, since customer loyalty is an important intangible asset of the firm and a prerequisite for its high competitive advantages.

In relation to this study, important is the internal structure of the firm, which is considered in the theory of contracts, where it is interpreted as a network of contracts, and the attention of researchers also focuses on the organizational structures of management that use firms in the business practice. These are simple or unitary structures (U) and complex and multidivisional $(\mathrm{M})^{22}$. The use of one or the other is associated with a number of factors but the performance of the firm depends on the successful choice of them.

The research of real processes occurring within the firm was carried out by representatives of the theory of property rights. In this concept, a firm is interpreted as a set of ownership rights to tangible assets. Use of assets is the owner's prerogative. He/she also defines the directions of

${ }^{21}$ Hojon, J. (2003). Ekonomicheskaya teoriya i instituty: Manifest sovremennoy institutsionalnoy ekonomicheskoy teorii [Economic Theory and Institutions: The Manifesto of Modern Institutional Economic Theory]. Moscow: Business. (in Russian)

${ }^{22}$ Williamson, O. E. (2001). Ekonomichni instytutsiyi kapitalizmu. Firma, marketynh, ukladannya kontraktiv [Economic institutions of capitalism. Firm, marketing, contracting]. Kiev: ArtEk. (in Ukrainian) 
activity, the strategy of the firm ${ }^{23}$. Such an approach provides an opportunity to identify problems of vertical integration and limits of a firm.

The construction of hierarchical relations of the firm and the problems of their development are studied in the agency theory. T. Eggertsson interprets them as follows: agency relations arise when some trustee delegates some rights to some agent who is obliged, in accordance with a formal or informal contract, to represent his/her interests in return for a certain remuneration ${ }^{24}$. In the firm as a hierarchical structure, each employee, with the exception of its highest and lowest levels, is simultaneously both a principal and an agent. The asymmetry of information is characterized by the fact that the agent has a larger array than the principal, and, hence, it is possible to use it to achieve own goals, that is, there is a risk of opportunistic behaviour. Formation and development of agency relations generate agency costs that relate to transaction costs and are investigated within the framework of a new institutional theory ${ }^{25}$. Reducing agency costs primarily involves reducing the level of opportunistic behaviour by increasing trust in the team and using such mechanisms as adversarial agents, the participation of agents in the profits and capital of the firm, and the use of a circular management organization in which agents perform the functions of the principal one after another ${ }^{26}$.

In the new institutional economic theory, firms are investigated not only as separate entities but as groups (populations) of homogeneous organizations. Herewith, the research tools developed by other sciences are used. Such an approach to the analysis of the firm is peculiar to the evolutionary theory of economic change, which explores the population on the basis of taking into account the rules of their individual behaviour, the interaction between themselves, and the appearance (disappearance) of the firm in this set. These rules provide an opportunity to analyse the changes that occur in the process of a firm's operation in the population.

\footnotetext{
23 Joskow, P. (2001). Spetsifichnost aktivov i struktura vertikalnykh otnosheniy: empiricheskiye svidetelstva [Asset specificity and vertical relationship structure: empirical evidence]. The nature of the firm. Ed. O. E. Williamson and S. J. Winter. Moscow: Business. (in Ukrainian); Hart, O. (2001). Nepolnyye kontrakty i teoriya firmy [Incomplete contracts and the theory of the firm]. The nature of the company. Ed. O. E. Williamson and S. J. Winter. Moscow: Business. (in Russian)

${ }^{24}$ Eggertsson, T. (2001). Ekonomicheskoye povedeniye i instituty [Economic behavior and institutions]. Moscow: Business. (in Russian)

${ }^{25}$ Stiglitz. J. (1987). Principal and Agent. The New Palgrave: A Dictionary of Economics. London. Macmillan.

${ }^{26}$ Oleinik, A. (2000). Institutsionalnaya ekonomika [Institutional economy]. Moscow: INFRA-M. (in Russian)
} 
The evolutionary theory explores the skills and routines that play a major role in ensuring the firm's effective performance. Routines, rather than optimal solutions, determine the behaviour of the firm. Routines also explain the fact that firms are not responding so quickly to changes in the external environment. The stability of routines is explained by the fact that they are formed over a fairly long period and are unique assets of the firm, for the development of which it makes appropriate costs. Change of routines worsens the relationship within the firm and beyond. Such an important value of routines is based on the fact that they represent the memory of the firm, the conditions of operation and development, and the purpose. Such a broad interpretation ensures their unique role in the firm.

In the market, the firm's behaviour, according to representatives of the evolutionary theory of economic change, is determined by the fact to which population of firms it relates. If the firm relates to a population of innovators, it takes a monopoly position in the market, dictates the price, and maximizes profits, thus displacing the most ineffective representatives of the population of conservatives. Conservatives are trying to survive. In the course of competition between innovators and conservatives, there is economic, technical, technological progress. The process of change and the firm's behaviour are studied by evolutionists on the basis of the use of computer models, which opens wide opportunities for studying the activity of individual firms but limits possibilities for generalizations on the functioning of the populations of firms. At the same time, the fact that this concept recognizes the existence of effective, less effective, and also ineffective firms in one population and studying their behaviour contributed to the approximation of the theoretical scheme to the real economy.

An important direction in the development of the new institutional theory of the firm is a competence-based theory, which develops in line with a new resource theory, initiated by E. Penrose ${ }^{27}$. Competences, like routines, are formed throughout the whole period of development of the firm, they are hardly exposed to imitate, and so competitors cannot copy and use them. At the same time, the firm is a concentration of production resources, and its unique properties in the form of competences are associated with the heterogeneity of knowledge about the use of resources, organization of production, training of skilled workers, etc. In modern conditions, this concept has developed in the theory of strategy ${ }^{28}$.

\footnotetext{
${ }^{27}$ Penrose, E. (1959).The Theory of the Growth of the Firm. Oxford Basil Black Well.

${ }^{28}$ Hamel, G., \& Prachalad, C. K. (1989). Strategic Intent. Harvard Business Review. Mai-June.
} 
The competence-based theory of the firm is based on the following main categories: competences - the ability of the firm to combine resources in order to achieve its goals; information - a set of structured data, through which it is possible to obtain new information; knowledge a set of cognitive abilities, skills and ability of firm employees to study; routine - a set of organizational interactions that are codified and adapted to solve specific problems of the firm's development. This direction of research of the firm differs in that it uses situational rationality in making decisions. This is explained by the fact that in an unstable environment, difficult decisions are made. Upon that, optimization calculations cannot be implemented, therefore, the decisions are satisfactory and correspond to one or another moment of the current situation. Calculations are taken into account in the context of routines that shape the behaviour of workers and firms.

A competence-based theory assumes that the firm's resources are specific, so they cannot simply be bought in the market. The resources are created and accumulated by the firm, which is developing in this process of creation and accumulation of resources. As a result, firms cannot have the same characteristics, they are unique. Focusing on the analysis of these problems provides an opportunity for conducting a deep study of production, which distinguishes the competence-based theory from other competences of the firm of institutional economic theory. Production is studied in terms of the ability of employees to combine resources, make decisions, and ensure achieving goals. These abilities are formed in the process of training and are decisive for the firm since they form the basis of its competences. Therefore, the training in this theory is given the main role. The conditions for the formation, evolution, and transformation of competences in the process of training are also important. This theory, as well as the evolutionary theory of economic change, attaches particular importance to the previous development of the firm, that is, it is said that previous investments and formed routines determine the future behaviour of the firm. But at the same time, the firm should not rely solely on previous development; it should take into account the complexity and changes in the environment, which, in conditions of uncertainty and rapid changes, can become decisive for it.

In the competence-based theory in the "information-knowledge" dichotomy, preference is given to knowledge, which is regarded as the ability of learning and cognitive properties of workers. In its turn, 
information is interpreted as a set of structured and codified data that cannot create new information, although it can be used to obtain new information. Knowledge generates new information, provides an opportunity to integrate it and use it in a new way.

Preferring the way of organizing production, the competence-based theory offers a kind of approach to the definition of the nature of the firm. The firm in its interpretation is a place of training, which has two levels: routine training, which involves repetition of actions and their simulation; training in the course of changing the nature of the firm. At the second level, there is a codification of knowledge implemented in the training process. K. Polanyi at one time noted that the basis is the difference between knowledge in general and codified knowledge ${ }^{29}$. The first ones are realized only by their owners, who often ignore them or do not have the opportunity to realize them. Such knowledge deepening requires high costs because they should be identified and the owner should be interested in their implementation. Codification of knowledge allows separating knowledge from the owner and form competences based on them that are difficult to simulate. Upon that, the training process should take the form of an organizational routine.

The competence-based theory, emphasizing the role of training in the creation of competences, suggested the justification of the existence of the firm not from the viewpoint of "failures" of the market but from the viewpoint of own advantages a firm has regardless of the market. It has its own effectiveness and provides activities that some individuals cannot. Advantages of the firm are associated with possibilities of information processing, conflict resolution, adaptation to changes ${ }^{30}$.

Competences determine the competitive advantages of the firm, so it must form them and be able to determine. S. Tywoniak believes that for the competences of the firm, which determine its competitive advantages, the following conditions must be fulfilled: cost: competence should provide the opportunity to use opportunism, neutralize the threats of the environment, and provide a significant contribution to the value of the product for the client; rarity: competence should be rarity; imitation difficulties: competitors should not be able to imitate it; longevity: competences should be used for a certain time, depending on the ways of technical innovations, the activities of other manufacturers, the

\footnotetext{
${ }^{29}$ Polanyi, M. (1966). The Tacit Dimension. Petersmith Publisher.

30 Menard, C. (1996). Ekonomika organizatsiy [Economics of organizations]. Moscow: INFRA-M. (in Russian)
} 
fundamental character of knowledge in competences; irreplaceability: competence should not have substitutes; appropriation: firms should be able to appropriate profits from the results of the use of competences ${ }^{31}$.

Competences explain the long-term operation of certain firms, and their lack - the existence of firms within a rather short period. At the same time, effectively operating firms focus on one or several core competences. O. Bouba-Olga explains this by such circumstances. Cognitive abilities of the firm's employees are limited, so they can concentrate only on a few training processes. This is one human knowledge space. Another one is characterized by the fact that a person receives ready information in it. The firm also considers the scope of knowledge and concentrates cognitive resources in one or two competences and develops, protects, identifies them ${ }^{32}$.

An important fact is that competence-based management is very expensive. The production, accumulation, and movement of strategic knowledge between the divisions of the firm require constant investment, so the firm selects and supports a limited number of basic competences. And, finally, there is declining productivity of the desire to disseminate knowledge to many types of activities ${ }^{33}$, so firms control them in close activities that require the same knowledge.

At the same time, firms may use non-core competences for other development paths that are not associated with the previous ones. In modern conditions, such opportunities are important for firms since they increase their flexibility, adaptability, and promote the effective use of existing potential.

\section{CONCLUSIONS}

The research of a modern firm by economic theory differs, firstly, in the formation of new approaches in the course of paradigmatic shifts in the very economic theory. First of all, it concerns methodological constructions that do not reflect the peculiarities of activities of real firms. This takes place through the introduction of social determinants, psychological factors in analysis in addition to purely economic parameters that enrich the content of the category and in an integrated manner reflects the system of relations that are formed in the firm, as

\footnotetext{
31 Tywoniak, S. (1998). Le modele des resources et des competences: un nouvean paradigme pour le management strategique? Repenser la strategie. Paris. Vouibert.

32 Bouba-Olga, O. (2003). L'economie de l'entreprise. Paris. Editions du Seuil.

${ }^{33}$ Richardson, G. (1972). The organization of Industry. The Economics Journal, vol. 87.
} 
well as provides an opportunity to determine the prospects for its development in conditions of uncertainty, fierce competition, and instability. The gradual shift away from the coercion of methodological individualism ensures the approach of the firm's theory to the solution of real problems existing in various industries and spheres of modern firms.

Secondly, modern economic theory, based on the analysis of economic relations, which are formed within the firm and the socioeconomic system as a whole, focuses on the analysis of the relationships that are formed based on a set of ownership rights in the process of transferring the control rights and the delegation of one or another functions. It contributes to the understanding of internal processes and provides an opportunity to build relationships with other firms, to form new formations on the basis of interfirm relations, to analyse not individual firms but their totality, and to substantiate the existence of not only successful but also less successful firms in the economy.

Thirdly, the development of the modern theory of the firm involves the inclusion of elements of economic knowledge in the analysis, which is organic for the theory of the firm, since the competences for a modern firm is an important component of its intangible assets that provide it with competitive advantages, prospects for development and prosperity. The firm's research in the competence-based theory provides an opportunity to determine its role and place in the process of formation of the social capital of society and withdraw from the understanding of the firm as a production function, fill it with the new modern content, and determine its true inwardness.

\section{SUMMARY}

The chapter analyses the following paths of development of the firm as the theory of transaction costs, contract theory, the theory of property rights, agency theory, competence-based theory, and the evolutionary theory of economic change. The reasons for changing the methodology of research of modern firms related to the underestimation of property rights, forms of organizations, and types of economic activity by the neoclassical economic theory are substantiated. The studies focus on defining the firm's target function in the presence of alternative limits, the conceptual difference between firm and market, and uncertainty inherent both in theoretical concepts and in real economic processes.

It is determined that theoretical concepts of the firm of neoinstitutional economic theory are based on the fact that the firm 
exists and develops due to the formation of an agreed type of behaviour of its employees, which differs from the antagonistic behaviour of market participants. It is substantiated that the contract theory and the theory of property rights reveal the internal structure and real processes of the firm's activity. It is determined that competence-based theory interprets the firm as a set of competences, information, knowledge, and routines, which are formed throughout the entire existence of the firm and are difficult to imitate. It is substantiated that in the evolutionary theory of economic change, not only individual firms are studied but their populations, where both competitiveness and unprofitable firms coexist.

\section{REFERENCES}

1. Alchian, Armen, \& H. Demsetz (1972). Production, Information Costs, and Economic Organization. American Economic Review, 62, 777-795.

2. Arkhiiereev, S. I. (2005). Transaktsionnyye izderzhki institutsionalizatsii fondovogo rynka [Transaction costs institutionalization of the stock market]. Kharkiv. (in Russian)

3. Bouba-Olga, O. (2003). L'economie de l'entreprise. Paris: Editions du Seuil.

4. Coase, R. (2001). Priroda firmy [The nature of the firm]. In the book: The nature of the company. Ed. O. Williamson and S. J. Winter Moscow: Business. (in Russian)

5. Joskow, P. (2001). Spetsifichnost aktivov i struktura vertikalnykh otnosheniy: empiricheskiye svidetelstva [Asset specificity and vertical relationship structure: empirical evidence]. The nature of the firm. Ed. O.E. Williamson and S.J. Winter. Moscow: Business. (in Ukrainian)

6. Eggertsson, T. (2001). Ekonomicheskoye povedeniye i instituty [Economic behavior and institutions]. Moscow: Business. (in Russian)

7. Gornyak, O. V. (2004). Firma v ekonomichniy teoriyi ta praktytsi hospodaryuvannya [Firm in Economic Theory and Practice of Management]. Odessa: Astroprint. (in Ukrainian)

8. Hamel, G., \& Prachalad C. K. (1989). Strategic Intent. Harvard: Business Review. Mai-June.

9. Hart, O. (2001). Nepolnyye kontrakty i teoriya firmy [Incomplete contracts and the theory of the firm]. The nature of the company. Ed. O. E. Williamson and S. J. Winter. Moscow: Business. (in Russian) 
10. Hojon, J. (2003). Ekonomicheskaya teoriya i instituty: Manifest sovremennoy institutsionalnoy ekonomicheskoy teorii [Economic Theory and Institutions: The Manifesto of Modern Institutional Economic Theory]. Moscow: Business. (in Russian)

11. Knudsen, Christian. (1986). Normal Science as a Process of Creative Destruction: From a Microeconomic to a Neoinstitutional Research Program. Paper presented at the International Symposium on Property Rights Organizational Forms and Economic Behavior. (P. 10). Lund: The Swedish Collegium for Advanced Study in the Social Sciences.

12. Lakatos, Imre. (1970). Falsification and the Methodology of Scientific Research Programs, Cambridge: Cambridge University Press.

13. Machlup, F. (1999). Teorii firmy: marzhinalistskiye, bikhevioristkiye i upravlencheskiye [Theories of the firm: marginalist, behavioral and managerial]. Milestones of economic thought. St. Petersburg: School of Economics. (in Russian)

14. Menard, C. (1996). Ekonomika organizatsiy [Economics of organizations]. Moscow: INFRA-M. (in Russian)

15. Nelson, R. R. (1981). Research of productivity Growth and Productivity Differences: Dead Ends and New Departures. Journal of Economic Literature, 29, 1029-64.

16. Nelson, R. R., \& Winter S. J. (2000). Evolyutsionnaya teoriya ekonomicheskikh izmeneniy [The evolutionary theory of economic change]. Moscow: ZAO Finstatinform. (in Russian)

17. Oleinik, A. (2000). Institutsionalnaya ekonomika [Institutional economy]. Moscow: INFRA-M. (in Russian)

18. Penrose, E. (1959). The Theory of the Growth of the Firm. Oxford: Basil Black Well.

19. Polanyi, K. (1993). Samoreguliruyushchiysya rynok i fiktivnyye tovary: trud, zemlya i dengi [Self-regulating market and fictitious goods: labor, land and money]. Thesis. T. 1. Vyp. 2, p. 15. (in Russian)

20. Polanyi, M. (1966). The Tacit Dimension. Petersmith: Publisher.

21. Richardson, G. (1972). The organization of Industry. The Economics Journal. Vol. 87.

22. Simon, H. A. (1999). Teoriya prinyatiya resheniy v ekonomicheskoy teorii i nauke o povedenii [Decision making theory in economics and behavior science]. Milestones of economic thought. St. Petersburg: School of Economics. (in Russian) 
23. Stiglitz, J. (1987). Principal and Agent. The New Palgrave: A Dictionary of Economics. London: Macmillan.

24. Tywoniak, S. (1998). Le modele des resources et des competences: un nouvean paradigme pour le management strategique? Repenser la strategie. Paris: Vouibert.

25. Williamson, O. E. (2001). Ekonomichni instytutsiyi kapitalizmu. Firma, marketynh, ukladannya kontraktiv [Economic institutions of capitalism. Firm, marketing, contracting]. Kyiv: ArtEk. (in Ukrainian)

\section{Information about the author:} Horniak O. V.

Doctor of Economic Sciences, Professor, Head of Department of Economics and Entrepreneurship, Odessa I. I. Mechnikov National University, Ukraine 